Hermann, Elfriede; Fuhse, Antonie (2018): Introduction: Dilemmas of Belonging in Indian Diasporas. In: Elfriede Hermann and Antonie Fuhse (eds.): India Beyond India: Dilemmas of Belonging. Göttingen: Göttingen University Press (Göttingen Series in Social and Cultural Anthropology, 12), pp. 11-24. Doi: 10.17875/gup2020-1261

\title{
1 Introduction: Dilemmas of Belonging in Indian Diasporas
}

\author{
Elfriede Hermann and Antonie Fubse
}

People's transnational mobilities, their activities to build homes in their countries of residence and their connectivities have resulted in multiplicities of belonging to encountered, imagined and represented communities operating within various political contexts. Migrants and their descendants labor to form and transform relations with their country of origin and of residence. People who see their origins in India but are now living elsewhere are a case in point. They have been establishing worldwide home places, whose growing number and vibrancy invite reconsideration of Indian diasporic communities and contexts in terms of 'India(s) beyond India.' Issues of belonging in Indian diasporas include questions of membership not only in the nation of previous and present residence and/or the nation of origin, but also in other communities and networks in political, economic, religious and social realms at local, regional or global levels. Yet, belonging - and especially simultaneous belonging - to various formations is rarely unambiguous. Rather, belonging in all its modes may entail dilemmas that arise from inclusions and exclusions. Bearing in mind such processes, the contributions to this volume endeavor to provide answers to the question of what kinds of difficulties members of Indian communities abroad encounter in connection with their identifications with and participation in specific collectivities. The underlying argument of all the essays collected is that members of Indian diasporas develop strategies to cope with the dilemmas they face in connection with their sense of belonging to particular communities, while they are subjected to specific power relationships. Thus, the volume sheds light on the ways in which dilemmas of belonging are being negotiated in intercultural fields. 


\section{Indian Diasporas}

The Indian diaspora is a global phenomenon. Thirty-one million Indians live outside India, as estimated by the Ministry of Overseas Indian Affairs (now under the Ministry of External Affairs). ${ }^{1}$ Migrants stemming from India and the surrounding states that once formed part of the British Raj can now be found in just about every country in the world (Lal 2006a: 10). These millions of people comprise not one homogenous Indian diaspora but mirror, in fact, the many different waves of Indian migration over hundreds of years. Motivated to leave India for multiple reasons - trade, work, security, education - they landed on many different shores. In contexts where their relation to India is at stake, these migrants and their descendants are referred to as 'persons of Indian origin' (PIO) and 'non-resident Indians' (NRI) (Lal 2006a: 11; Bhat this volume). The Indian diaspora is already, as many publications demonstrate, a considerable field of study in the humanities (see e.g. Vertovec 2000; Lal, Reeves and Rai 2006; Oonk 2007; Jacobsen 2008; Safran, Sahoo and Lal 2009). Indeed, this field has been attracting increasing attention from a plethora of disciplines - among them, cultural and social anthropology, gender studies, history, literary studies, religious studies, sociology and South Asian studies. The topics covered have been many and multiple: The nation, migration and transnational processes, identity, ethnicity and diversity, social relationships and gender, economics, politics, religion, the media, the performing and other arts, as well as studies delving into intercultural, transcultural and global processes.

Taking our lead from The Encyclopedia of the Indian Diaspora (Lal, Reeves and Rai 2006), we have decided to retain the term 'Indian diaspora,' which lends itself particularly well to the historical perspective we are including. Alternatively, we could have chosen to talk of a 'South Asian diaspora' - a term consonant with the fact that the migrants did not stem solely from India within its present borders, but rather from territory in what is now Pakistan, Bangladesh, Burma and Sri Lanka (see e.g. Vertovec 1991; van der Veer 1995; Shukla 2001). When referring to the Indian diaspora as configurations of persons who trace their origins, wholly or partly, back to the Indian subcontinent, we do not wish to suggest they are fixated on this fact. Rather, we can safely assume that this relationship is only one among many, each one having its own weighting.

In choosing the title 'India beyond India' we disavow any intention of viewing either India or the Indian diaspora as a solid or homogeneous block. Even if we have opted for generic concepts, we construe India - both as a historical presence and contemporary state - and South Asia generally no differently than the multiple Indian diasporas, i.e. as heterogeneous configurations which have been exposed to a diversity of associations - at times, even dissociations - and which find themselves in a state of permanent transformation. 'India beyond India,' a designation Roman Loimeier (this volume) devised, has the potential of going beyond the common

\footnotetext{
${ }^{1}$ http://mea.gov.in/images/attach/NRIs-and-PIOs_1.pdf (accessed 18 June 2018).
} 
phrase of 'Little Indias.' If 'India beyond India' seems, at first glance, to foreground the relationship between Indian diasporas and India, it should be emphasized, however, that Indian communities abroad have also been forging particular relationships with the states in which they are located. In addition, Indians have been creating networks between their communities worldwide. All these relationships are of the utmost importance regarding issues of belonging.

\section{Historical Contexts of Indian Diasporas}

Foreign trade of South Asian merchants can be dated back to around the second century AD (Mann 2015: 216). In the following centuries, different merchant communities (Chettiars, Khojas, Sindhis) developed further trading networks that eventually spanned the East African coast and Southeast Asia (Brown 2006; McPherson 2006; Mann 2015). Indian trading posts were established in ports such as Mogadishu, Mombasa and Zanzibar. These were the beginnings of permanent settlements in these areas and the formation of an Indian diaspora on the Swahili coast (Mann 2015: 216). This diaspora was a complex network of traders and sailors, in fact, a collection of communities defined by language, religion and regional background (McPherson 2006: 34; Sheriff 2010). The arrival of the Portuguese, Dutch and English trading companies and their subsequent fight over trading monopolies for spices and textiles had a major influence on the activities of the Indian merchants in the Indian Ocean and in Southeast Asia (Mann 2015: 216-218). Several trading communities, such as the Sindhis, were able to take advantage of the structures of the British Empire and expand their own trade; others were less fortunate. Nevertheless, these communities have been of great importance for the structure and development of the Indian diasporas that followed. Communities that go back to these trading networks still exist in many parts of the Indian Ocean world (east and west) (Loimeier this volume).

Many parts of South Asia had been under the control of the British Empire since the $16^{\text {th }}$ century and India was incorporated as a crown colony in 1858 . This development had a great impact on the Indian migration, especially after the abolition of slavery and the subsequent introduction of the system of indentured labor (Mann 2015: 219-225). As there was a constant need for cheap laborers for the plantation economies, millions of people were sent to the Caribbean, the Indian Ocean, Africa, the Pacific, and South and Southeast Asia (Lal 2006b). Fleeing bad conditions (such as famines and unemployment) in India at that time, many of the indentured laborers were hoping to improve their economic situation and return to India after their work contracts expired (Mann 2015: 225-226). In fact, many of the laborers did return to India, but more decided to stay in their new homes. The system of indentured labor and everything connected to it - the travel on the kalapani (black water), the work and living conditions on the plantations, the relationship to the colonial power and the other communities in the new country - have been the starting point 
for the formation of a lot of different Indian diasporas in many parts of the world. Furthermore, this development was an important historical event not only for India or the Indian communities, but also the many different communities and countries that have been involved in this process. This is clearly shown by the histories of Mauritius (see e.g. Eisenlohr 2006; Schnepel this volume), Trinidad (Vertovec 1995; Munasinghe 2001; Khan 2004; Munasinghe this volume) and Fiji (Lal 2004; Trnka 2008; Kaplan this volume; Kelly this volume) and the postcolonial struggles fought in these countries to define who belongs to the newly established nations.

Indian migration changed in the middle of the $20^{\text {th }}$ century. For the first time, not only students from the Indian upper class, but also larger groups of migrants were drawn to the center of the empire and later the Commonwealth. Great Britain had been the main destination until the liberalization of immigration laws in Australia, Canada and New Zealand in the 1960s intensified the migration to the Commonwealth. Part of these waves of migration were the so-called 'twice displaced,' Indians who left East African countries for reasons of insecurity (Khadria 2006, 2012). The USA and the Gulf region have become important destinations for different groups of migrants since the 1970s. The oil-rich Middle East has attracted laborers who worked on the many construction sites and had a considerable impact on the Indian economy, especially in Kerala state, due to the remittances they sent to their families (Osella and Osella 2000; Vora 2008).The introduction of flexible policies for highly skilled migrants in the USA and Canada spurred the migration of Indian engineers, doctors, scientists and managers (Brown 2006: 25). Canada changed its immigration policies in the 1960s to admit people with much needed skills (Brown 2006: 54). India soon became one of the most important sending countries for skilled immigrants to Canada. In this volume, Swati Shirwadkar focuses on Indian women in Canada.

The migration from South Asia to European countries had multiple causes and took many different routes. In the case of Germany, Indian migration was documented from the early $20^{\text {th }}$ century when Indian freedom fighters who sought support for their fight against colonial rule arrived and students were attracted by German universities (Gottschlich 2012: 1). After World War II, it was again Indian students, mostly from the fields of engineering and natural sciences, who found their way to universities and companies in Germany. Germany has recently been facing a skills shortage, gearing its migration policies towards attracting highly skilled migrants and students from India (Fuhse this volume). The Tamils in Kamala Ganesh's study (this volume) fled Sri Lanka's civil war and came to Germany and Switzerland in the 1980s and 1990s (Baumann, Luchesi and Wilke 2003: 8-9). Most of the Tamil refugees were Hindus who started to found prayer groups soon after their arrival. By now, the Sri Lankan Tamils have built several temples in Germany and other European countries, among them the Sri Kamadchi-Tempel in Hamm-Uentrop (Baumann, Luchesi and Wilke 2003: 11).

The routes and destinations of Indian migrants have been various regarding the contemporary migration of Indian students, scientists, laborers and maids to many different parts of the world. Their roots in India have been as different as their routes 
of migration. Various routes and roots are articulated by the many organizations that Indians have established on the grounds of a common background (e.g. regional, religious) or a common migration experience (Bhat this volume). The Indian diaspora is, thus, highly heterogeneous and represents the linguistic, religious and cultural diversity of India. This fact evokes the question of how the dimensions and dynamics of belonging play out in India beyond India.

\section{Debating Dilemmas of Belonging}

Integrating historical contexts of Indian migration into their analyses, the contributions to this volume are alert to the extent to which issues of belonging in postcolonial times bear the imprint of historical legacies, such as politics, religion, social and ethnic dynamics, as well as the attendant modes of 'othering.' In this context, we wish to investigate the challenges that go along with belonging.

A person usually experiences a sense of belonging to a variety of communities during their life (e.g. Cohen 1982; May 2013). This also applies particularly to people whose personal history is shaped by their own or their forbears' migration. Belonging is culturally constituted, while membership of as well as loyalties to local, regional or national communities and people's emotional attachment to places depend on sociopolitical processes and the accompanying power relationships (Kempf, van Meijl and Hermann 2014: 15). If the granting of access or denial of membership to such collectivities and places is geared towards constructing fundamental 'others' and distancing 'them' from 'us,' political projects are at work that Nira Yuval-Davis (2006: 204), with reference to John Crowley, called "the politics of belonging." Being fully, partly or hardly accepted in various communities, however, often causes people to feel torn between their acquired and more or less desired memberships. People find themselves in situations in which they have no choice but to choose between allegiance to one or the other community that is of emotional significance to them, or else between one or the other place, being aware of adverse effects this decision will, in all probability, have. They find themselves in what John Kelly (this volume) has aptly termed "dilemmas of belonging."

In turning our attention to diasporic configurations of persons whose ancestors originated from the Subcontinent or else who left it during their own lifetime, we seek to elucidate how Indians beyond India cope with dilemmas of belonging. We ask: What are the kinds of dilemmas that emerge in specific configurations? What kinds of strategies do people develop to deal with the specific dilemmas of belonging they face? Our debate focuses on three fields of belonging and related dilemmas in three parts of this volume. The first part offers a broad perspective on various ways in which Indianness and multiplicities of belonging are articulated in transnational space. In the second part, we zoom in on issues of belonging that Indian diasporas have been facing in their efforts to contribute to the making of a nation in their new 
countries of residence. In the third part, the politics and violence of belonging in Indian diasporas are explored.

\section{Belonging in Transnationl Space}

An ever-increasing number of people are becoming mobile and engage in social relations and practices that cross borders and, thus, live in a transnational social space (Pries 2001; Levitt and Glick Schiller 2004). This space, of course, also includes those people who, for various reasons, are not mobile but are connected to migrants around the world. Living in a transnational space means the simultaneous connection to and embedding in many different lifeworlds (Luckmann 1978; Strauss 1978) and, thus, a multiplicity of belonging. This first part of the volume offers two different perspectives on this multiplicity of belonging in transnational space. Chapter 2 focuses on various Indian diaspora organizations. Chapter 3 engages with the topic on the level of the personal navigation of multiple modes of belonging.

Chandrashekhar Bhat, in chapter 2, regarding Indian diaspora organizations, shows the multitude of Indian organizations that developed based on different modes of belonging. After discussing four streams of migration that are the basis of today's heterogeneous Indian diaspora, Bhat continues to describe two categories of Indian diaspora organizations: Global organizations that are based on the notion of a pan-Indian identity and those that are based on regional and linguistic, religious or caste identities. His discussion of different pan-Indian organizations reveals the interesting point that migration history can also be employed as a marker of belonging. Hence, different pan-Indian global organizations developed for PIOs and NRIs. The former category consists mostly of the descendants of Indian indentured laborers, the latter of Indian professionals whose migration to different parts of the world started in the middle of the $20^{\text {th }}$ century. Both global organizations lobbied in India for the development of institutionalized connections between India and its many diasporas. Chandrashekhar Bhat summarizes the policies that were established by the Indian government in this regard and, thus, shows the success of the pan-Indian organizations in advocating for Indians beyond India. In addition to these organizations that are based on the notion of an Indian identity, Bhat discusses some of the many diaspora organizations that are based on regional and linguistic, religious or caste belonging. These organizations foster not only transnational networks among Indians abroad, but also links to their region of origin. The connections between the diasporas and India are visible in the many investments that Indians beyond India make in their respective regions and communities of origin. Thus, in his conclusion, Bhat argues for the notion of 'Indianness' that transcends geographical boundaries and is transnational in character.

In chapter 3, Antonie Fuhse focuses on a younger generation of mobile Indians: Students and researchers who come to Germany for the completion of a $\mathrm{PhD}$ or a postdoctoral fellowship. She uses the concept of 'biographic navigation' (Vigh 2007, 2009; Pfaff-Czarnecka 2012) as a tool to analyze individual strategies in the 
negotiation of the multiplicity of belonging. Antonie Fuhse discusses four facets of belonging that are central for the students and researchers' biographic navigation in transnational space. One of these facets involves the practices of belonging at various festivals that are organized by the Indian association in Göttingen. These festivals provide a space for social interaction and a platform to perform the 'Indian' culture in familiar ways. However, these events also pose the question of what India and Indianness actually mean to the young students and researchers. The second dimension of belonging that the author discusses is the importance of the regional background for the formation of circles of friends and the organization of festivals. Fuhse shows that the formal organization for Indians in Göttingen can act as a regime of belonging, as it tries to unite all Indian students and researchers under the common and rather apolitical notion of 'unity in diversity.' The third facet that the author analyzes is the young Indians' professional belonging as 'scientists.' Coming to Germany and specifically to Göttingen, a well-known university city, is part of the students and researchers' strategies to achieve certain professional and personal goals. Many expressed the feeling that Göttingen is the right place to fulfill these goals. However, a lot of the students and researchers do not plan to stay in Germany. Antonie Fuhse discusses the (imagined) futures of the young Indians as the fourth aspect of their navigation through transnational space. Many of the young students and researchers expressed their wish to go back to India at some point in time. The author argues that this idea of a return to India is an important anchor in the young Indians' biographic navigation, irrespective of the realization of this vision. Antonie Fuhse concludes that being Indian is only one facet of the students and researchers' multiple modes of belonging that intersects with other dimensions and is constantly constructed and reconstructed in their biographic navigation in transnational space.

\section{Belonging and Nation Building}

Belonging figures prominently in diasporic people's efforts to contribute to nation building or seek other forms of self-determination in their countries of residence. As the contributions by Viranjini Munasinghe, Martha Kaplan, John Kelly, Burkhard Schnepel and Roman Loimeier show, this holds true for Indian communities in Trinidad, Fiji, Mauritius and Zanzibar. For the most part, Indian diasporas in Trinidad, Fiji, and Mauritius descend from indentured laborers who worked in sugar plantations, and in the case of Zanzibar from trading communities. Historical legacies of colonial rule and racial discourses have shaped their conditions - and dilemmas - of belonging to their countries of birth, albeit to different extents. Thus, autochthony has played an important role in Fiji, where it was mobilized by ethnonationalist elements among ethnic Fijian iTaukei to counter the emotional belonging of various other cultural communities, including the Indo-Fijian part of the population, but it did not feature in either Trinidad or Mauritius. In postcolonial times, Indian diasporic communities in all these countries have developed strategies to pursue equal citizenship rights. However, they are still seeking recognition of their sense of 
belonging in terms of political representation in Trinidad and Fiji, whereas they have achieved full electoral and citizenship rights in Mauritius. In Zanzibar, political oppression prevented the development of feelings of belonging to the nation. Rather, the sense of belonging to distinct religious and/or ethnic communities shapes the presence of Indians in Zanzibar today.

Viranjini Munasinghe, in chapter 4 "Anxieties of Belonging: East Indians and the Cultural Politics of the Nation in Trinidad," turns analytically to emotions of belonging that were involved in Indo-Trinidadian strategies to achieve full inclusion in the nation. She traces the history of Indian indentured laborers who, after their arrival in the middle of the $19^{\text {th }}$ century, were positioned outside the 'incipient nation' in Trinidad by colonial discourses of race. From then on, Indo-Trinidadians were constructed in opposition to 'Creoles,' a broad category that came to include people of African and European ancestry and signified local, indeed native status. Descendants of Indians came to be seen as culture bearers, being accorded an exceptional status in the colony and the Caribbean state of Trinidad and Tobago. Focusing on a span of time of intensified cultural and political contestation of the nation in this postcolonial state, Viranjini Munasinghe argues that the cultural excess ascribed to Indo-Trinidadians prevented them from being fully included in discourses that have constituted the nation of Trinidad. Members of the Indian diaspora in Trinidad have faced a dilemma of belonging by claiming national sameness as Trinidadians and ethnic difference as Indians. While Indo-Trinidadians, mobilized by their anxieties of belonging, have developed discursive strategies for national inclusion that reproduce difference, they have also engaged in processes of interculturation that connect them with Afro-Trinidadians. This intercultural space of commonalities is still, however, dominated by discourses of difference that all communities in the country adhere to and are perpetuating Indo-Trinidadian dilemmas of belonging to the Trinidadian nation.

In chapter 5, Martha Kaplan introduces us to "Dilemmas of Belonging in Fiji," focusing on "Constitutions, Coups, and Indo-Fijian Citizenship." Analyzing the struggle for national belonging fought by descendants of Indian migrants in the context of the political history of Fiji in the southwest Pacific, she pleads for a historical anthropology of dilemmas. From a historical perspective, postcolonial Fiji emerges with a baggage of legacies from the colonial era. Among these legacies were racial discourses ascribing fundamental difference to autochthonous Fijians, called iTaukei (owners of the land), by comparison to descendants of Indians, most of whom had come as indentured laborers to work on Fijis sugar cane plantations in the late $19^{\text {th }}$ and early $20^{\text {th }}$ centuries. Among these historical legacies were also political privileges the colonial British had accorded to the autochthonous Fijians. Thus, structures had been put in place for an unequal belonging in terms of citizenship when Fiji gained its political independence in 1970. Since then, postcolonial Fiji has had a number of constitutions that have followed not only democratic elections, but also and especially a number of coups. In 1987 and 2000, these coups espoused, once again, political privileges for autochthonous Fijians, whereas the coup of $2006 \mathrm{did}$ not proclaim 
iTaukei political paramountcy but imposed military rule until general elections were held in 2014. Confronted with ethnonationalist discourses, Indo-Fijian aspirations of national belonging have frequently been frustrated. In view of these sociopolitical processes, Martha Kaplan argues that the dilemma of belonging for Indo-Fijians is linked to the question of self-determination: Should they stay and pursue a withdrawal strategy as a minority, or pursue a strategy of seeking self-determination by emigration and the hardship this might bring?

John Kelly in chapter 6 zooms in on "Dilemmas of Belonging in Fiji" with an analytical eye on "Shanti, Swaraj, and the Problem of Political Armies." Like Martha Kaplan, he sees the dilemma of belonging that Indo-Fijians have been facing in postcolonial Fiji crystallized in the question of whether they should stay, aspiring to a minority status, or take on the burden of emigrating. Turning to cultural conceptions, he argues that the Indo-Fijians' specific dilemma is one between the virtues of shanti, meaning peace, and swaraj, self-rule. He calls this dilemma a "dilemma of virtue" and explains that this means whether to define the situation, to valorize or even transvalue possible courses of action, in one light or the other. When, in Fiji's postcolonial history of successive coups, Indo-Fijians doubted the prospect of national belonging, their tactic was to act according to their value of shanti as emotional peace in the face of hardship. However, they were not only seeking shanti, but also pursuing the tactic of swaraj, self-rule, and this in a political context of military omnipresence. Talking of political armies, John Kelly compares Fiji's political trajectory to military occupations in the Asian Highlands. He finds that the wisdom of Indo-Fijian commitment to non-violence, the complexity and tragedy in their cultural dialogue with ethnic Fijians, and even some tangible grounds for hope become clearer when the political dynamics of the Asian Highlands and the Fiji Islands are understood in one analytic field. In his conclusion, Kelly points to the prerequisites for self-determination of both of the largest groups and continuing peace in Fiji despite all the ruptures: Whether autochthonous Fijian mana, power, and Indo-Fijian shanti, peace, can be reconciled in moves toward a common future.

In chapter 7, Burkhard Schnepel writes about "Guests without a Host: The Indian Diaspora(s) in Mauritius." He describes the specificity of the Indian diaspora - understood as a plurality of diasporas - in this state in the southwest Indian Ocean by discussing seven characteristics of Indo-Mauritian groups. These particularities are: 1) The Indian diasporas in Mauritius have many different roots and routes, with the majority of today's Indo-Mauritians having descended from indentured laborers who came after $1834 ; 2$ ) Indo-Mauritians have established a new life relatively close to 'home'; 3) the Indian diaspora in Mauritius is substantial in absolute numbers but even more so in relative numbers; 4) the Indian diaspora in Mauritius is not the only one there; 5) all Mauritians come from elsewhere, value their diasporic links and have a diasporic consciousness; 6) the Mauritian kind of nationalism can be called '(multi)ethnonationalism,' based on the idea of the legitimate existence of a number of different ethnic groups building their nation; and 7) the role model for ethniccum-diasporic identity on Mauritius is provided by the Indian diaspora, especially 
its Hindu variant. Taken together, these particularities offer Indo-Mauritians a fill of opportunities for belonging to various communities, be they characterized by roots in different regions in India, language, ethnicity, religion, education, rural or urban location, economic success or professional standing, or be they the larger entities of the Mauritian nation or the broad category of Asians. As Burkhard Schnepel observes, Indo-Mauritians may select from and mobilize some part(s) of their identifications with these communities depending upon contexts. During the democratization processes, all citizens of Mauritius achieved equal citizenship rights with Indo-Mauritians being successful in terms of political representation.

Roman Loimeier looks closely at the historical development of the Indian diaspora in East Africa and particularly Zanzibar in chapter 8. Through his detailed account of the history of the highly diverse Indian diaspora, he illustrates how political agendas and sentiments influence the possibilities of having a place in a nation and, thus, of creating a sense of belonging. He also shows how most of the Indian communities in East Africa have maintained strong religious and social boundaries and thus remained fragmented even under political and economic pressure. Thus, most Indians decided not to abandon their identification with the Indian diaspora and their roots in India, even during the independence movements in East Africa and the accompanying pressure to commit themselves to new identities. The Indian diaspora has also maintained exclusive practices among themselves. The many different places for religious practice in Zanzibar - temples, mosques and churches - illustrate the plurality of the Indian community. In view of these facts, Loimeier concludes that communal divisions along the lines of regional and social descent, occupation and religion have continued to define Indian communities in East Africa.

\section{Politics of Belonging and Violence}

The third part of this volume is concerned with the relationship between belonging and violence in two very different ways. Swati Shirwadkar in chapter 9 on domestic violence in Indian diasporas in North America demonstrates how modes of belonging influence the access to policies and programs to reduce domestic abuse. She argues for paying greater attention to the intersection of gender and ethnicity in the analysis of domestic violence and, thus, for policies that take the women's community belonging into account. Shirwadkar's analysis shows that there are multiple obstacles that prevent Indian immigrant women in Canada and the United States from taking the measures available against their abusive husbands. Among other things, the women fear losing their connection to the Indian community and to their families, while they also fear the stigma of divorce. Furthermore, the author shows that Indian immigrant women prefer the intervention from within the community and are, thus, reluctant to call for "outside" help from social workers. Domestic violence, thus, also becomes an issue in the negotiation of more general concerns of 'Indian' and 'Western' values and what it means to belong to the Indian immigrant community in North America. 
In chapter 10, Kamala Ganesh shows that how the Sri Lankan Tamils relate to their homeland is influenced by the experience of forced displacement and the civil war. Ganesh stresses the importance of religious practices and temples for coping with the stress of leaving home and building a new life in a foreign country. Tamil religiosity is not only an existential response to the loss of the homeland, but also a political one. The temples in the diaspora become forums for LTTE (Liberation Tigers of Tamil Eelam) propaganda and mobilization. However, Ganesh makes a point of showing that the responses of Sri Lankan Tamils to trauma and feelings of loss are various. Some become active in homeland politics and even support violent methods, others criticize the LTTE and violence. The articulation of belonging to Sri Lanka is multiple and depends on personal history and values.

\section{Conclusion: Diversities of Dilemmas and Coping Strategies}

It becomes clear in the debate in which the contributors to this volume engage that dilemmas of belonging have been emerging that differ in their degrees of intensity in the Indian diasporas in which they have worked. Dilemmas often arise from the difficulty in choosing which of one's manifold memberships of collectivities to prioritize: Belonging to a diasporic Indian or South Asian community that is characterized by religion, region of origin, language or caste; or belonging to a group that is putting great emphasis on their roots in India and is globally organized; and, importantly, belonging to the supraregional Indian diaspora in a particular country and/or to the nation of the country of residence, as diverse as this may be. A comparison between the ethnographic case studies collected in this volume suggests that the degree of intensity of dilemmas is determined by a number of factors. The first factor to be considered is that of the type of diaspora: Is it a diaspora that grew from an earlier community of merchants (i.e. in East African countries), a diaspora founded by former indentured laborers (i.e. in Mauritius, Trinidad and Fiji) or a diaspora mainly constituted by labor migrants who travelled to other countries in the past few decades (i.e. in Canada and Europe)? The second factor to be considered is the extent of relationships that current diasporic groupings maintain to the country of origin in South Asia. The third factor that plays a crucial role in the constitution and maintenance of belonging is the politicization of cultural similarities or differences regarding religion, region of origin, language, class or caste - all of them aspects that are mobilized for the purpose of inclusion or fundamental exclusion. Dilemmas of belonging arise frequently if not always, so our debate showed, from historical processes and political contexts. The existence of ethnonationalist claims on the part of one or more of the other ethnic communities in a given country poses a special challenge to belongingness. A fourth factor is composed of legal, economic, religious, social and moral orders - in short, cultural configurations - in postcolonial countries that are the home for Indian diasporas. All these factors may come together, be complemented by yet other factors and unfold their efficacy. 
As the contributions to this volume show, members in Indian communities abroad have to cope with the specific dilemmas they encounter. They are subjected to power relationships, structures, events and encounters that may entail hostilities and set up conditions for their belonging that are hard to accept. But they have also been developing cultural strategies for dealing with these dilemmas of belonging - strategic practices that confirm, alter or even dissolve attachment to particular communities. In any case, members of the many Indias beyond India are exercising their agency in relating to their past, making their living in the present and imagining their future.

\section{References}

Baumann, Martin, Brigitte Luchesi, and Annette Wilke, eds. 2003. Tempel und Tamilen in zweiter Heimat: Hindus aus Sri Lanka im deutschsprachigen und skandinavischen Raum. Würzburg: Ergon.

Brown, Judith M. 2006. Global South Asians: Introducing the Modern Diaspora. Cambridge: University Press.

Cohen, Anthony P. 1982. "Belonging: the Experience of Culture." In Belonging: Identity and Social Organisation in British Rural Cultures, edited by Anthony P. Cohen, 1-17. Manchester: University Press.

Eisenlohr, Patrick. 2006. Little India: Diaspora, Time, and Ethnolinguistic Belonging in Hindu Mauritius. Berkeley: University of California Press.

Gottschlich, Pierre. 2012. "German Case Study." CARIM-India Research Report 2012/03. http://cadmus.eui.eu/handle/1814/20822.

Jacobsen, Knut A., ed. 2008. South Asian Religions on Display: Religious Processions in South Asia and in the Diaspora. London: Routledge.

Kempf, Wolfgang, Toon van Meijl, and Elfriede Hermann. 2014. "Introduction: Movement, Place-Making and Cultural Identification: Multiplicities of Belonging." In Belonging in Oceania: Movement, Place-Making and Multiple Identifications, edited by Elfriede Hermann, Wolfgang Kempf, and Toon van Meijl, 1-24. New York: Berghahn Books.

Khadria, Binod. 2006. "The Migration of Professionals." In The Encyclopedia of the Indian Diaspora, edited by Brij V. Lal, Peter Reeves, and Rajesh Rai, 70-75. Singapore: Editions Didier Millet.

—_ 2012. India Migration Report 2010-2011: The Americas. Cambridge: University Press.

Khan, Aisha. 2004. Callaloo Nation: Metaphors of Race and Religious Identity Among South Asians in Trinidad. Durham: Duke University Press.

Lal, Brij V., ed. 2004. Bittersweet: The Indo-Fijian Experience. Canberra: Pandanus Books.

. 2006a. "Introduction." In The Encyclopedia of the Indian Diaspora, edited by Brij V. Lal, Peter Reeves, and Rajesh Rai, 10-15. Singapore: Editions Didier Millet. 
. 2006b. "The Indenture System." In The Encyclopedia of the Indian Diaspora, edited by Brij V. Lal, Peter Reeves, and Rajesh Rai, 46-53. Singapore: Editions Didier Millet.

Lal, Brij V., Peter Reeves, and Rajesh Rai, eds. 2006. The Encyclopedia of the Indian Diaspora. Singapore: Editions Didier Millet.

Levitt, Peggy, and Nina Glick Schiller. 2004. "Conceptualizing Simultaneity: A Transnational Social Field Perspective on Society." International Migration Review 38 (3): 1002-39. doi:10.1111/j.1747-7379.2004.tb00227.x.

Luckmann, Benita. 1978. “The Small Life-Worlds of Modern Man.” In Phenomenology and Sociology: Selected Readings, edited by Thomas Luckmann, 275-90. New York: Penguin Books.

Mann, Michael. 2015. South Asia's Modern History: Thematic Perspectives. New York: Routledge.

May, Vanessa. 2013. Connecting Self to Society: Belonging in a Changing World. Basingstoke: Palgrave Macmillan.

McPherson, Kenneth. 2006. "Indian Maritime Communities." In The Encyclopedia of the Indian Diaspora, edited by Brij V. Lal, Peter Reeves, and Rajesh Rai, 32-36. Singapore: Editions Didier Millet.

Munasinghe, Viranjini. 2001. Callaloo or Tossed Salad? East Indians and the Cultural Politics of Identity in Trinidad. Ithaca: Cornell University Press.

Oonk, Gijsbert, ed. 2007. Global Indian Diasporas: Exploring Trajectories of Migration and Theory. Amsterdam: Amsterdam University Press.

Osella, Filippo, and Caroline Osella. 2000. Social Mobility in Kerala: Modernity and Identity in Conflict. London: Pluto Press.

Pfaff-Czarnecka, Joanna. 2012. Zugehörigkeit in der mobilen Welt: Politiken der Verortung. Göttingen: Wallstein Verlag.

Pries, Ludger, ed. 2001. New Transnational Social Spaces: International Migration and Transnational Companies in the Early Twenty-First Century. London: Routledge.

Safran, William, Ajaya K. Sahoo, and Brij V. Lal, eds. 2009. Transnational Migrations: The Indian Diaspora. London: Routledge.

Sheriff, Abdul. 2010. Dhow Cultures of the Indian Ocean: Cosmopolitanism, Commerce and Islam. London: Hurst.

Shukla, Sandhya. 2001. "Locations for South Asian Diasporas." Annual Review of Anthropology 30 (1): 551-72. doi:10.1146/annurev.anthro.30.1.551.

Strauss, Anselm. 1978. "A Social World Perspective." Studies in Symbolic Interaction 1: 119-28.

Trnka, Susanna. 2008. State of Suffering: Political Violence and Community Survival in Fiji. Ithaca: Cornell University Press.

van der Veer, Peter, ed. 1995. Nation and Migration: The Politics of Space in the South Asian Diaspora. Philadelphia: University of Pennsylvania Press.

Vertovec, Steven, ed. 1991. Aspects of the South Asian Diaspora. Delhi: Oxford University Press. 
1995. "Hindus in Trinidad and Britain: Ethnic Religion, Reification, and the Politics of Public Space." In Nation and Migration: The Politics of Space in the South Asian Diaspora, edited by Peter van der Veer, 132-56. Philadelphia: University of Pennsylvania Press.

- 2000. The Hindu Diaspora: Comparative Patterns. London: Routledge.

Vigh, Henrik. 2007. Navigating Terrains of War: Youth and Soldiering in GuineaBissau. New York: Berghahn Books.

__ 2009. "Motion Squared: A Second Look at the Concept of Social Navigation." Anthropological Theory 9 (4): 419-38. doi:10.1177/146349960935 6044.

Vora, Neha. 2008. "Producing Diasporas and Globalization: Indian Middle-Class Migrants in Dubai." Anthropological Quarterly 81 (2): 377-406. doi:10.1353/ anq.0.0010.

Yuval-Davis, Nira. 2006. "Belonging and the Politics of Belonging." Patterns of Prejudice 40 (3): 197-214. doi:10.1080/00313220600769331. 